\title{
International Firms' Market Orientation and Use of Knowledge: Implications for Market Information Systems
}

\author{
Anders Pehrsson \\ Linnaeus University \\ Anders.Pehrsson@1nu.se
}

\begin{abstract}
Efficient dissemination of market knowledge within the industrial firm is essential to global competitiveness. However, use of knowledge regarding firm's foreign markets needs more attention in research. This paper extends the understanding of the industrial firm's use of its stock of market knowledge. Relying on the knowledgebased view of the firm and the market orientation construct, a conceptual model and propositions are developed. These focus on associations between foreign subsidiary's value-adding scope and its growth, and the moderating roles of market knowledge created locally, or somewhere else in the corporation. An understanding of the importance of knowledge of foreign markets and use situations will facilitate the design of market information systems that include creation and sharing of knowledge within international industrial firms.
\end{abstract}

\section{Introduction}

Integration of a foreign subsidiary into the industrial firm's corporate framework is central to the firm's global competitiveness [31]. The subsidiary may then be able to exploit relatedness among units of the firm and, thereby, enjoy synergies [29]. The integration is facilitated if knowledge collected from different foreign markets is efficiently disseminated within the firm. Such dissemination is a component of firm's market orientation, that is, its capability of identifying and satisfying customer needs more effectively than competitors based on generation and dissemination of market intelligence [18]. However, coordination of activities within the firm is necessary for dissemination of market information and delivery of unique values to customers [26].

While results of some studies support a positive importance of sharing information within the firm [13], other studies found no positive direct effects of greater information sharing and inter-functional coordination on firms' competitiveness [19]. In addition, effects may be contingent on environmental turbulence and availability of external networks [20].

Thus, there is need for more research on boundaries to the firm's use of market knowledge collected from different foreign markets. Examination of this topic will facilitate the design of information systems that include creation and dissemination of knowledge within international firms.

The purpose of this paper is to explore market orientation of international industrial firms and, thereby, contribute to literature on international strategy. Essentially, the paper extends the understanding of boundaries to the use of the industrial firm's stock of market knowledge. The paper pays attention to a foreign subsidiary's use of knowledge of customers and competitors in a situation where it seeks to profit from its scope of value-adding activities. Managerial implications are put forward regarding market information systems that enable efficient market orientation. Such systems build on extensive capabilities of managing knowledge [7].

A conceptual model and propositions are developed. In particular, the model pays attention to associations between a foreign subsidiary's valueadding scope and its performance, and the moderating roles of deep market knowledge created locally and broad market knowledge created somewhere else in the corporation.

\section{The knowledge-based view of the firm}

To study the matter I apply the knowledge-based view of the firm which is an outgrowth of the resource-based view [39]. In the former, the firm is considered to be a stock of knowledge $[12,25]$ which may be based on experience or explicit [28]. Thus, uneven knowledge distribution among competing 
firms explains performance differences and learning capability is a key advantage of leading firms.

The knowledge-based view relies on some assumptions [12]: (1) experience-based knowledge is difficult to transfer between firms, (2) it is more costeffective to use the same knowledge than to build new knowledge, and (3) it is efficient to create specialized knowledge.

The knowledge base of a firm follows two dimensions [8]. Firm's number of knowledge domains represents knowledge breadth, while the complexity of each domain captures knowledge depth. This paper focuses on knowledge of competitors and customers that may be created anywhere in the firm and then transferred to a particular foreign subsidiary. Such knowledge is referred to as broad market knowledge as it is created outside the subsidiary and, therefore, generally concerns other market domains with different competitors and customers. The subsidiary may be able to assimilate the incoming knowledge if the subsidiary possesses enough learning capacities.

\section{Conceptual model and propositions}

International strategy literature provides attempts to explore the matter $[2,7,14]$. However, although growth of a foreign subsidiary would be a central matter to most global firms, relationships between value-adding activities of the subsidiary and its growth is not examined enough. For example, a framework for the understanding of relationships between a foreign subsidiary's market knowledge and its value-adding scope has been presented [32]. Here, the scope consists of the number of valueadding activities. These include upstream product development and production, and downstream sales and services. Yet, the framework is illustrated by four subsidiary cases and has not been tested. Also, the framework did not incorporate effects on subsidiary performance.

The conceptual model of this paper (Figure 1) adds to the field by incorporating an association between the subsidiary's value-adding scope and its growth, and moderating effects of market knowledge created locally and elsewhere in the firm. The model captures market knowledge transferred from a hub of knowledge creation and transfer such as the parent firm.

The model includes subsidiary performance in terms of growth as this is a common objective of the global firm. The growth may concern sales growth, revenue growth, or any other relevant specification.
Furthermore, the model is an outgrowth of the resource-based view which emphasizes advantages based on heterogeneous resource distribution among competitors [39]. Growth of the subsidiary should therefore be seen in relation to growth of the main competitors.

Financial or operational measurements would be alternative specifications of performance. Yet, transfer pricing policies and corporate desires for different performances among subsidiaries may weaken the validity of such measurements.

Hence, the model rests on the notion that efficient international operations require market orientation and knowledge in terms of experienced-based knowledge of competitors and customers. The knowledge may be created in the local market, or elsewhere in the corporation if, for example, the knowledge concerns competitors that appear in several markets. The assimilation of knowledge essentially facilitates subsidiary's evaluation of the behavior of competitors [30, 41] and the costs a potential customer may encounter when switching to another supplier [4].

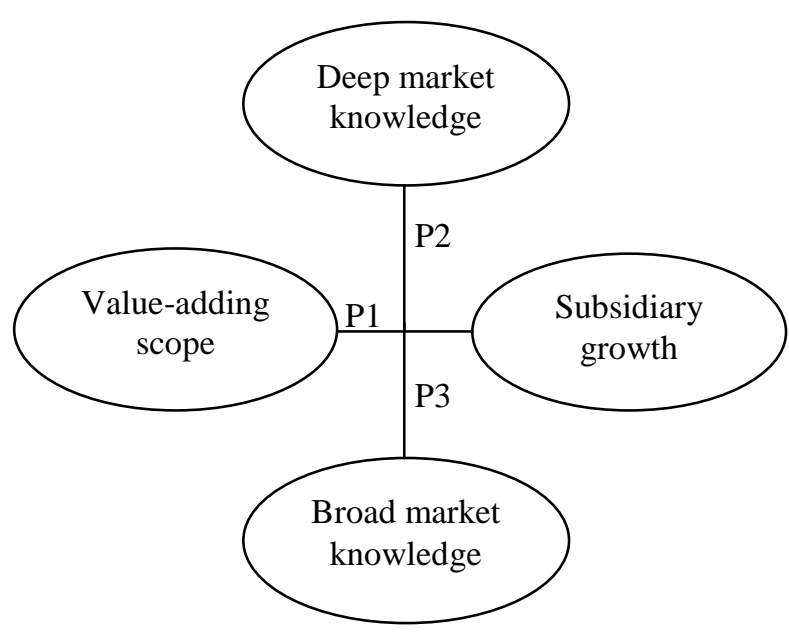

Figure 1. Conceptual model

\subsection{Main association of value-adding scope}

The resource-based theory [39] implicates that growth of an industrial firm's foreign subsidiary requires a consideration of available excess resources 
that may be facilitate the growth. The value-adding scope of the subsidiary may provide such resources [34]. Essentially, growth of a foreign subsidiary may rely on use of excess resources emanating from local upstream activities such as product development and production, or the downstream activities of sales and services. The former activities generally bring extensive fixed costs and a long term market commitment [22], while the latter activities are generally more flexible.

If the foreign subsidiary is engaged in upstream activities it is responsible for engineers that, for example, customize products or perhaps take part in the development of new products. Furthermore, the subsidiary may also be able to carry out upstream production activities, such as assemblies or manufacturing operations, and thereby employ engineers to take care of the production activity.

In accordance with the arguments put forward above the first proposition predicts a positive association between the breadth of the foreign subsidiary's value-adding scope and growth.

Proposition 1 (P1): There is a positive association between the breadth of a foreign subsidiary's valueadding scope and its growth.

\subsection{Moderating association of deep market knowledge}

A subsidiary that knows how to access potential customers in the foreign market would benefit from tailoring its value activities to needs of customers. Frequently, the subsidiary needs to incorporate advanced activities such as product development and assembly production to be able to fulfill a diversity of product requirements of individual customers.

The A subsidiary operates in the US and belongs to a Swedish firm, and it provides an example [33]. It has accumulated great experiences of how to access customers and is able to customize products to fit needs of individual customers. The subsidiary brings a broad range of air purification products to the market and these are used indoor. Individual consumers constitute a large target group, while companies and authorities are other important groups. However, the subsidiary sometimes encounters obstacles in trying to find an appropriate mix of retailers of different character which makes it hard to access important target customers.

In principle, exogenous barriers such as obstacles to access customers are structural parts of the market
[37]. Exogenous barriers include, for example, customers' switching costs, loyalties among buyers and sellers, sales channel availability, and scale effects such as a need for low costs. For example, a relationship between a customer and another supplier means that the customer may be less interested in turning to the A subsidiary if a switch implies any costs. Through the accumulation of market knowledge such as knowledge of exogenous barriers the growth of $\mathrm{A}$ is facilitated.

Thus, the subsidiary builds knowledge of the local market by systematically collecting and analyzing comments from customers. Results are communicated within the organization and to the parent firm regularly. Also, meetings are held frequently that involve sales staff and product development experts of the firm in order to customize products to fit needs and requirements of local customers.

By collecting, analyzing, and disseminating market information the subsidiary becomes more skilled in treating a range of customers and identifying target groups [41], how to find available sales channels [11], and treat competition [16]. This market orientation favors subsidiary's engagement in upstream value-adding activities such as product development and production. The outcome is expressed by the second proposition.

Proposition 2 (P2): Greater local market knowledge strengthens the positive association between foreign subsidiary's upstream value-adding activities and its growth.

\subsection{Moderating association of broad market knowledge}

The character of knowledge transferred to, or from, the individual subsidiary is decisive to the role of the subsidiary in the corporate framework [1]. In a seminal work Eriksson, Johanson, Majkgård, and Sharma [10] establish the importance of creating and transferring experiential knowledge in order to facilitate firms' internationalization. Several later studies contribute to the understanding of flows of knowledge within international firms $[14,23,24,35$, $6,38,41]$.

According to Gupta and Govindarajan [14] knowledge transferred within an international firm incorporates different analysis levels. First, an individual unit such as a foreign subsidiary may be focused in studies of flows of knowledge from the 
unit, or to the unit. Second, the joint behavior of pairs of units may be captured in studies of mutual knowledge transfer. Third, the all individual units of the corporation may be analyzed in order to study different directions of knowledge transformation.

Gupta and Govindarajan focus on the individual subsidiary and found positive associations between the size of subsidiary's knowledge stock and the extent of outflow of knowledge, and between the stock size and the number of channels for sharing knowledge. The inflow of knowledge was found to be positively associated with channel diversity, and the subsidiary's motivation to acquire knowledge and capability of absorbing it.

More precisely, Roth et al. [36] propose that effective transfer of knowledge within an international firm is contingent on subsidiary's marketing experience and speed of changes of customers' preferences and technology. A lack of experience in marketing a certain product motivates managers to use market knowledge created elsewhere on the corporation, while such knowledge may reduce uncertainty stemming from changes pertaining to customers and technology.

The character of sources of knowledge transferred to a foreign subsidiary is crucial when it comes to integrating it into the corporate framework. Yet, some research on internationalization processes advocates that a firm expands its local value-adding scope through evolutionary steps [15, 21]. However, this view does not acknowledge the role of corporate strategy. Thus, the strategy should be viewed as a source of market knowledge created elsewhere in the corporation that impacts relationships pertaining to the foreign subsidiary's value-adding scope.

Strategy scholars show that exploiting a common knowledge base is an efficient way to achieve growth [3]. However, transfer of market knowledge to the foreign subsidiary brings benefits as long as there is relatedness regarding competitors and customers [29]. Such relatedness makes it easier for the subsidiary to assimilate incoming knowledge and integrate it into its knowledge stock. This corporate strategy explanation of subsidiary growth is similar to explanations provided by internalization theory [5]. This stipulates that the firm's tries to internalize and integrate activities and, thereby, reduce transactions costs.

Besides business relatedness there are other determinants of knowledge transfer which essentially are based on corporate strategy: organizational linkages [27] and geographic distance [42]. Furthermore, the transfer is embodied by individuals and organizational routines. For example, a subsidiary that is highly related to the core business unit of the parent firm tends to perform well because market similarities facilitate the design of common routines and subsidiary's assimilation of knowledge.

The B subsidiary of a Swedish firm operates in the US [32] and exemplifies the theoretical arguments. A great amount of market knowledge is being transferred from the parent firm to the subsidiary. This enables the subsidiary to replicate the parent firm's value-adding activities and exploit the common knowledge.

$\mathrm{B}$ has the same product range as the parent firm and it includes several products using pneumatics and ultra-high pressure hydraulics. The major target groups consist of companies such as those producing wind power components, nuclear energy components, and off shore oiling drafts. Since the start in 1986 the subsidiary addresses business customers that are less sensitive to price. Besides engaging nationwide distributors the subsidiary targets original equipment manufacturers. The competitors include those that emphasize low prices in large market segments and those sell at high prices in limited segments. As similar competition structures appear on all major foreign markets the US subsidiary benefits from exploiting market knowledge created elsewhere in the corporation.

During the first years of the establishment B was responsible for just sales. A greater number of individual customers then started to ask for product customizations. As a response, the subsidiary initiated product design and production of small batches. The extended value-adding scope means a replication of the scope of the parent firm that dominates the corporation as a whole.

Provided that a foreign subsidiary is enough knowledgeable it may generally replicate the dominating value-adding scope of a corporation [40]. The arguments and case illustration put forward above show that transfer of relevant market knowledge facilitates formation of local value-adding activities that replicate the dominating value-adding scope. Replication of common activities enables greater exploitation of market knowledge originating from a corporate core, and this favors growth of the foreign subsidiary.

Proposition 3 (P3): Greater market knowledge created elsewhere in the firm strengthens the similarity between a foreign subsidiary's valueadding scope and the firm's dominating scope, implying a positive association with subsidiary growth.

\section{Conclusions and contributions}


The proposed associations regarding a foreign subsidiary's value-adding scope and its growth, including the moderations due to the extent of deep and broad market knowledge, extend the understanding of the use of the industrial firm's stock of market knowledge. The conceptual model particularly underscores the importance of the situation in which the knowledge is used. Thus, the model shows that a foreign subsidiary's intention to expand based on its scope of value-adding activities determines the use of knowledge. Furthermore, the predictions suggest contributions to international strategy literature as they articulate the importance of deep and broad market knowledge to growth on a foreign market. The propositions may be turned into testable hypotheses in future research.

\section{Managerial implications}

The results of this paper extend the understanding of the importance of foreign market knowledge and constitute a ground for designing an effective corporate market information system. This would facilitate the sharing of market knowledge within the international industrial firm and support firm's orientation towards markets. Also, corporate-wide dissemination of market knowledge makes it easier to integrate a variety of foreign subsidiaries into a corporate framework enabling an efficient market orientation.

Market orientation is important as it expresses a set of corporate-level principles that are intended to create a superior offering to customers [17]. In order to effectively orient the corporation towards the market, the information system should contain essential information about competitors and customers of firms' foreign subsidiaries and other organizational units. The information may be collected in different markets, or centrally.

The system would be more efficient if it in addition provides appropriate ways of analyzing the information and creating knowledge. For example, information concerning global competitors that appear on several markets could be analyzed in a common way, while local competitors may be analyzed separately.

Dissemination and sharing of the market knowledge within the firm would be a ground for the formulation of, for example, responses to needs of customers and actions of global and local competitors. Appropriate responses that imply superior offerings may include product customization or broader solutions to customers' problems, or building of long-term relationships with individual customers.

Yet, it is important to recognize the complexity of designing market information systems and need for related knowledge management capabilities [7]. The design is, for example, complicated as the use of information is due to the use situation as illustrated in this article. In addition, dynamic market conditions seem to drive the extent of information usage [36] and greater dynamism means that benefits of building systems tend to exceed the costs. In other circumstances, such as those in stable markets, costs may be too high to motivate design of advanced information systems. A major lesson would be that a market information system should be adapted to needs and experiences not only of corporate management, but also of subsidiary management.

\section{References}

[1] F. Achcaoucaou, P. Miravitlles, F. León-Darder, "Knowledge sharing and subsidiary R\&D mandate development: a matter of dual embeddedness", International Business Review, 2014, Vol. 23, pp. 76-90.

[2] N. Åkerman, "Knowledge-acquisition strategies and the effects on market knowledge: profiling the internationalizing firm", European Management Journal, 2015, Vol. 33 No. 2, pp. 79-88.

[3] J. Barney, Gaining and Sustaining Competitive Advantages, Addison-Wesley, Reading, MA, 1997.

[4] T.H. Brusk, R. Dangol, and J.P. O'Brien, "Customer capabilities, switching costs, and bank performance", Strategic Management Journal, 2012, Vol. 33 No. 13, pp. 1499-1515.

[5] P. Buckley and M. Casson, The Future of Multinational Enterprise, Macmillan, London, 1976.

[6] J.S. Casillas, A.M. Moreno, F.J. Acedo, M.A. Gallego, E. Ramos, "An integrative model of the role of knowledge in the internationalization process", Journal of World Business, 2009, Vol. 44, pp. 311-322.

[7] A.S. Cui, D.A. Griffith, and S.T. Cavusgil, "The influence of competitive intensity and market dynamism on knowledge management capabilities of multinational corporation subsidiaries", Journal of International Marketing, 2005, Vol. 13 No. 3, pp. 32-53.

[8] L.M. DeLuca and K. Atuahene-Gima, "Market knowledge dimensions and cross-functional collaboration: examining the different routes to product innovation 
performance", Journal of Marketing, 2007, Vol. 71 No. 1, pp. 95-112.

[79] J.H. Dunning, Multinational Enterprises and the Global Economy, Addison-Wesley, Reading, MA, 1993.

[10] K. Eriksson, J. Johanson, A. Majkgård, and D.D. Sharma, "Experiential knowledge and cost in the internationalization process", Journal of International Business Studies, 1997, Vol. 28, No. 2, pp. 337-360.

[11] Y. Fang, M. Wade, A. Delios, and P.W. Beamish, "International diversification, subsidiary performance, and the mobility of knowledge resources", Strategic Management Journal, 2007, Vol. 28 No. 10, pp. 1053 1064.

[12] R.M. Grant, "The knowledge-based view of the firm", in Choo, C.W. and Bontis, N. (Eds), The Strategic Management of Intellectual Capital and Organizational Knowledge, Oxford University Press, Oxford, pp. 133-148, 2002.

[13] A. Grinstein, "The effect of market orientation and its components on innovation consequences: a meta-analysis", Journal of the Academy of Marketing Science, 2008, Vol. 36, pp. 166-173.

[14] A.K. Gupta and V. Govindarajan, "Knowledge flows within multinational corporations", Strategic Management Journal, 2000, Vol. 21 No. 4, pp. 473-496.

[15] J. Johanson and J.E. Vahlne, "Business relationship learning and commitment in the internationalization process", Journal of International Entrepreneurship, 2003, Vol. 1, pp. 83-101.

[16] D.J. Ketchen, C.C. Snow, and V.L. Hoover, Hoover, "Research on competitive dynamics: recent accomplishments and future challenges", Journal of Management, 2004, Vol. 30 No. 6, pp. 779-804.

[17] A.H. Kirca, S. Jayachandran, and W.O. Bearden, "Market orientation: a meta-analytic review and assessment of its antecedents and impact on performance", Journal of Marketing, 2005, Vol. 69, No. 2, pp. 24-41.

[18] A.K. Kohli and B. Jaworski, "Market orientation: the construct, research propositions, and managerial implications", Journal of Marketing, 1990, Vol. 54, April, pp. 1-18.

[19] F. Langerak, "The effect of market orientation on positional advantage and organization performance", Journal of Strategic Marketing, 2003, Vol. 11, June, pp. 93-115.

[20] R.P. Lee, Q. Chen, D. Kim, and J.L. Johnson, "Knowledge transfer between multinational corporations' headquarters and their subsidiaries: influences on and implications for new product outcomes", Journal of International Marketing, 2008, Vol. 16, No. 2, pp. 1-31.

[21] Y. Luo and S.L. Wang, "Foreign direct investment strategies by developing country multinationals: a diagnostic model for home country effects", Global Strategy Journal, 2012, Vol. 2 No. 3, pp. 244-261.

[22] E. Maitland, E.L. Rose, and S. Nicholas, "How firms grow: clustering as a dynamic model of internationalization", Journal of International Business Studies, 2005, Vol. 36, pp. 435-451.

[23] X. Martin and R. Salomon, "Tacitness, learning, and international expansion: a study of foreign direct investment in a knowledge-intensive industry", Organization Science, 2003, Vol. 14, No. 3, pp. 297-311.

[24] R. Mudambi, L. Piscitello, and L. Rabiossi, "Reverse knowledge transfer in MNEs: subsidiary innovativeness and entry modes", Long Range Planning, 2014, Vol. 47, pp. 49-63.

[25] X. Martin and R. Salomon, "Knowledge transfer capacity and its implications for them theory of multinational corporation", Journal of International Business Studies, 2003, Vol. 38, No. 4, pp. 356-373.

[26] J.C. Narver and S.F. Slater, "The effect of a market orientation on business profitability", Journal of Marketing, 1990, Vol. 54, No. 4, pp. 20-35.

[27] N. Nohria and S. Ghoshal, The Differentiated Network: Organizing Multinational Corporations for Value Creation, Jossey-Bass, San Francisco, CA, 1997.

[28] I. Nonaka, "A dynamic theory of organizational knowledge creation", Organization Science, 1994, Vol. 5, No. 1, pp. 14-37.

[29] A. Pehrsson, "Business-relatedness and strategy moderations: impacts on foreign subsidiary performance", Journal of Strategy and Management, 2010, Vol. 3, No. 2, pp. 110-133.

[30] A. Pehrsson, A. (2014), “Firms' customer responsiveness and performance: the moderating roles of dyadic competition and firm's age", Journal of Business \& Industrial Marketing, 2014, Vol. 29, No. 1, pp. 34-44.

[31] A. Pehrsson, "Firm's strategic orientation, market context, and performance: literature and opportunities for international strategy research", European Business Review, 2016, Vol. 28, No. 4, pp. 378-404.

[32] A. Pehrsson and T. Pehrsson, "Consistent resource base of a foreign subsidiary's greenfield expansion", European Business Review, 2014, Vol. 26, No. 1, pp. 6478. 
[33] A. Pehrsson and T. Pehrsson, "Competition barriers and foreign subsidiary growth: propositions on the contextual role of strategic orientation", International Journal of Business Competition and Growth, 2015, Vol. 4, No. 1/2, pp. 3-23.

[34] M.E. Porter, Competitive Advantage: Creating and Sustaining Superior Performance, The Free Press, New York, NY, 1985.

[35] S. Prashantham, "Toward a knowledge-based conceptualization of internationalization", Journal of International Entrepreneurship, 2005, Vol. 3, 37-52.

[36] M.S. Roth, S. Jayachandran, M Dakhli, and D.A. Colton, "Subsidiary use of foreign marketing knowledge", Journal of International Marketing, 2009, Vol. 17, No. 1, pp. 1-29.

[37] W. Shepherd, The Economics of Industrial Organization, Prentice-Hall, Englewood Cliffs, NJ., 1979.

[38] A. Tuppura, S. Saarenketo, K. Puumalainen, A. Jantunen, and K. Kyläheiko, "Linking knowledge, entry timing and internationalization strategy", International Business Review, 2008, Vol. 17, pp. 473-487.

[39] W.P. Wan, R.E. Hoskisson, J.C. Short, and D.W. Yiu, "Resource-based theory and corporate diversification: accomplishments and opportunities", Journal of Management, 2011, Vol. 37 No. 5, pp. 1335-1368.

[40] R. White and T. Poynter, "Strategies for foreignowned subsidiaries in Canada", Business Quarterly, 1984, Vol. 48, pp. 59-69.

[41] P.L. Yeoh, "International learning: antecedents and performance implications among newly internationalizing companies in an exporting context", International Marketing Review, 2004, Vol. 21, No 4/5, pp. 511-535.

[42] S. Zaheer, "Overcoming the liability of foreignness", Academy of Management Journal, 1995, Vol. 38, pp. 341364. 